\title{
Extended-release calcifediol in stage 3-4 chronic kidney disease: a new therapy for the treatment of secondary hyperparathyroidism associated with hypovitaminosis D
}

\author{
Mario Cozzolino $^{1}\left[\right.$ Paola Minghetti ${ }^{2} \cdot$ Pierluigi Navarra $^{3}$
}

Received: 31 May 2021 / Accepted: 31 August 2021 / Published online: 9 October 2021

(c) The Author(s) 2021

\begin{abstract}
A high percentage of patients with chronic kidney disease have hypovitaminosis $\mathrm{D}$, which is a driver of secondary hyperparathyroidism and an important factor in chronic kidney disease-mineral and bone disorder. Vitamin D deficiency (serum total $25-\mathrm{OH}$ vitamin D levels $<30 \mathrm{ng} / \mathrm{mL}$ ) occurs early in the course of chronic kidney disease and treatment guidelines recommend early intervention to restore $25-\mathrm{OH}$ vitamin $\mathrm{D}$ levels as a first step to prevent/delay the onset/progression of secondary hyperparathyroidism. The vitamin D forms administered to replace $25-\mathrm{OH}$ vitamin D include cholecalciferol, ergocalciferol, and immediate- or extended-release formulations of calcifediol. Most patients with intermediate-stage chronic kidney disease will develop secondary hyperparathyroidism before dialysis is required. Control of parathyroid hormone levels becomes a major focus of therapy in these patients. This article focuses on the position of extended-release calcifediol in the treatment of patients with stage 3-4 chronic kidney disease and secondary hyperparathyroidism with hypovitaminosis D. Several characteristics of extended-release calcifediol support its use in the intermediate stages of chronic kidney disease. The pharmacokinetics of extended-release calcifediol make it effective for replenishing 25-OH vitamin D levels, with minimal impact on vitamin D catabolism from fibroblast-growth factor-23 and CYP24A1 upregulation. Extended-release calcifediol increases circulating 25-OH vitamin D levels in a dose-dependent manner and lowers parathyroid hormone levels by a clinically relevant extent, comparable to what can be achieved by administering active vitamin D analogues, though with a lower risk of hypercalcaemia and hyperphosphataemia. Active vitamin D analogues are reserved for patients undergoing dialysis or pre-dialysis patients with severe progressive secondary hyperparathyroidism.
\end{abstract}

Keywords Chronic kidney disease $\cdot$ Calcifediol $\cdot$ Parathyroid hormone $\cdot$ Secondary hyperparathyroidism · Vitamin D . Vitamin D insufficiency

Mario Cozzolino

mario.cozzolino@unimi.it

1 Renal Division, ASST Santi Paolo e Carlo, Department of Health Sciences, University of Milan, Milan, Italy

2 Department of Pharmaceutical Science, Università degli Studi di Milano, Milan, Italy

3 Department of Healthcare Surveillance and Bioethics, Section of Pharmacology, Catholic University Medical School, Fondazione Policlinico Universitario A. Gemelli-IRCCS, Rome, Italy 


\section{Introduction}

Chronic kidney disease (CKD) is a major public health problem, with an estimated global prevalence of $11-13 \%$ [1]. CKD is progressive, with most patients developing CKDmineral and bone disorder and increased risks of fractures, cardiovascular disease, and reduced life expectancy [2-4]. CKD disrupts phosphorus and calcium homeostasis, and these perturbations lead to secondary hyperparathyroidism characterized by elevated parathyroid hormone levels and parathyroid hyperplasia [5], which are early events in most patients [6]. Secondary hyperparathyroidism is a critical component of CKD-mineral and bone disorder that manifests early during the progression of renal disease, occurring in approximately 40 to $80 \%$ of patients with stage 3 or 4 CKD [6]. In patients with stage $3 / 4 \mathrm{CKD}$, parathyroid hormone levels independently predict fractures, vascular events and death [7].

Phosphate retention and accumulation due to kidney damage is an early driver of secondary hyperparathyroidism. High serum phosphate triggers the release of fibroblast growth hormone 23 (FGF23) from bone, which, in turn, increases parathyroid hormone levels and inhibits activation of 25-hydroxy vitamin $\mathrm{D}(25(\mathrm{OH}) \mathrm{D})$ by suppressing $25(\mathrm{OH}) \mathrm{D}-1 \alpha$-hydroxylase expression [8]. Low levels of activated $1,25(\mathrm{OH}) 2 \mathrm{D}$ promote the progression of secondary hyperparathyroidism via multiple pathways, including decreased intestinal absorption of calcium that further stimulates parathyroid hormone secretion [6]. This causes progressive parathyroid gland hyperplasia with associated reduced responsiveness to calcium, vitamin D and FGF23 levels that gradually leads to autonomous parathyroid hormone secretion, (tertiary hyperparathyroidism) [9]. Early intervention is needed to slow progression, preserve bone health and minimise ectopic calcification.

The prevalence of vitamin D insufficiency is higher in patients with CKD than in the general population $[6,10$, 11]. Causes may include decreased vitamin $D$ activation and increased catabolism due to the effects of elevated FGF23 expression $[12,13]$. Although there is no consensus regarding optimal $25(\mathrm{OH}) \mathrm{D}$ levels in patients with $\mathrm{CKD}$ [14], guidelines define vitamin D sufficiency as serum total $25(\mathrm{OH}) \mathrm{D}$ levels $\geq 30 \mathrm{ng} / \mathrm{mL}$ [15], which is consistent with the 2011 Endocrine Society definition of 30-100 ng/ $\mathrm{mL}$ [16]. Studies in patients with CKD suggest that higher $25(\mathrm{OH}) \mathrm{D}$ levels are required to suppress parathyroid hormone levels and effectively treat secondary hyperparathyroidism [17-19].

Current guidelines recommend monitoring vitamin D status in pre-dialysis patients with CKD and supplementing with nutritional vitamin D (cholecalciferol or ergocalciferol) to delay the onset of secondary hyperparathyroidism $[15,20]$.

This article focuses on the position of Rayaldee ${ }^{\circledR}$, an extended-release (in Europe the term "prolonged-release" is used) calcifediol formulation that raises $25(\mathrm{OH}) \mathrm{D}$, lowers parathyroid hormone levels, and is approved for the treatment of secondary hyperparathyroidism in adults with CKD Stage 3 or 4 and vitamin D insufficiency or deficiency [21, 22].

\section{Issues with current management of secondary hyperparathyroidism in pre-dialysis CKD}

Currently, the best strategy for 25(OH)D administration aimed at treating secondary hyperparathyroidism in patients with CKD remains controversial [23]. The choice is complicated and CKD stage-dependent. Several treatment options exist (Table 1). The ideal agent would normalize 25(OH)D levels and suppress parathyroid hormone, without significantly affecting FGF23 levels or calcium and phosphorus homeostasis. Such an agent should have a low risk for hypercalcaemia, ectopic calcification and oversuppression of parathyroid hormone.

None of the agents in Fig. 1 has the ideal characteristics identified. In clinical practice, active vitamin D or an analogue is often prescribed to suppress parathyroid hormone in patients with secondary hyperparathyroidism.

In an observational cohort study conducted in 24 nephrology centres in Italy [25], prescription of active vitamin D or analogues was found to have progressively increased, starting from the early stages of CKD. However, guidelines from Kidney Disease Improving Global Outcomes (KDIGO) recommend that active vitamin D or analogues for secondary hyperparathyroidism treatment should be introduced only in late stages of CKD and end-stage renal disease in dialysis, and that their use should be reserved for patients with uncontrolled or rapidly increasing parathyroid hormone levels [26]. Active vitamin D and analogues are associated with a higher risk of hypercalcaemia [27]. Moreover, active vitamin D and analogues do not restore $25(\mathrm{OH}) \mathrm{D}$ levels and have the collateral effect of further reducing $25(\mathrm{OH}) \mathrm{D}$ levels by increasing FGF23. Because of this, active vitamin D and analogues must be combined with a nutritional vitamin $\mathrm{D}$ or a vitamin $\mathrm{D}$ prohormone (i.e., dual vitamin D therapy) [28].

Table 2 presents an overview of the 3 classes of vitamin D agents used for vitamin D repletion and modifying CKD-mineral and bone disorder parameters.

There is an urgent, unmet need for agents that can control parathyroid hormone levels and manage secondary 
hyperparathyroidism by optimizing serum $25(\mathrm{OH}) \mathrm{D}$ levels in pre-dialysis CKD patients who have vitamin D insufficiency or deficiency, without perturbing calcium and phosphate equilibrium or inducing excessive release of FGF23.

\section{Nutritional vitamin D}

Evidence for supplementation with cholecalciferol or ergocalciferol in late-stage CKD is based on very limited clinical studies, both in quality and in statistical power, and have not shown consistent results with regard to parathyroid hormone suppression [30, 31].

\section{Prohormones}

Vitamin D prohormones like $1 \alpha(\mathrm{OH}) \mathrm{D}$, or $25(\mathrm{OH}) \mathrm{D}$ can be classified into those that require $1-\alpha$-hydroxylase activation, and those that are already hydroxylated in the 1- $\alpha$-position. It is now known that extra-renal $1-\alpha$-hydroxylase can activate nutritional and prohormone vitamin D forms [32]; moreover, patients with pre-dialysis CKD have substantial renal 1- $\alpha$-hydroxylase activity. Calcifediol (25-hydroxyvitamin D3) is a long-lasting form of prohormone (half-life approximately 25 days after repeated daily dosing in patients with stage 3 or 4 CKD) that provides substrate for 1- $\alpha$-hydroxylation [21]. When administered in an immediate-release formulation, it increases $25(\mathrm{OH}) \mathrm{D}$ levels more rapidly and effectively than nutritional vitamin $\mathrm{D}$, but is not effective at suppressing parathyroid hormone levels [33]. Immediate-release calcifediol reduces parathyroid hormone by clinically meaningful amounts ( $\geq 30 \%)$ only when administered at doses that both raise serum 25(OH)D to supra-physiological levels (>100 ng/ $\mathrm{mL}$ ) and increase the risk of hypercalcaemia [29, 33-35]. This need for high doses of calcifediol to suppress parathyroid hormone may be due to an increase in FGF23 in response to the rapid rise in serum $25(\mathrm{OH})$ D levels obtained with immediaterelease calcifediol.

\section{Active vitamin D}

Calcitriol (1,25 dihydroxy vitamin D3) and other active ( $1 \alpha$-hydroxylated) forms of vitamin D can effectively suppress parathyroid hormone levels in pre-dialysis patients with CKD; however, these agents are associated with an increased risk of hypercalcaemia and ectopic calcification, and do not replenish 25(OH)D substrate levels [36].

\section{Active vitamin D analogues}

Like active forms of vitamin $\mathrm{D}$, active analogues do not require activation by $1 \alpha$-hydroxylase (CYP27B1), and therefore their activity is not subject to physiological regulation. They increase intestinal absorption of calcium and phosphorus, and their tolerability is limited by hypercalcaemia and/ or hyperphosphataemia and the risk of vascular calcification [37-39]. As with active forms of vitamin D, these agents fail to correct circulating $25(\mathrm{OH}) \mathrm{D}$ levels that are important for extra-renal production of $1,25(\mathrm{OH}) 2 \mathrm{D}[40,41]$, and therefore must be administered together with nutritional vitamin $\mathrm{D}$ or prohormones. Finally, these active analogues can trigger the feedback mechanism of FGF23-induced vitamin D degradation, further reducing vitamin D levels. Because of this, and in the absence of data supporting an improvement in hard clinical outcomes, they are not recommended for routine use in patients with pre-dialysis CKD unless they have severe and progressive hyperparathyroidism [26].

\section{Extended-release calcifediol}

An extended-release formulation of calcifediol has been developed to treat secondary hyperparathyroidism in nondialysis patients with CKD. Rayaldee ${ }^{\circledR}$ (OPKO Health/Vifor Fresenius Medical Care Renal Pharma) is an orally administered, extended-release formulation of $25(\mathrm{OH}) \mathrm{D} 3$ that is

Table 1 The effect of current treatment options for secondary hyperparathyroidism in patients with stage 3-4 CKD on mineral and bone disorder parameters (Adapted from Sprague et al. [24])

\begin{tabular}{|c|c|c|c|c|c|c|}
\hline Drug class & Active & $25(\mathrm{OH}) \mathrm{D}$ & $\mathrm{Ca}$ & $\mathbf{P}$ & PTH & FGF-23 \\
\hline $\begin{array}{l}\text { Nutritional } \\
\text { vitamin D }\end{array}$ & $\begin{array}{l}\text { Cholecalciferol } \\
\text { Ergocalciferol }\end{array}$ & 仓े & - & - & -1 & - \\
\hline Prohormone & IR calcifiediol & 仓 & - & - & -1 & 仓 \\
\hline $\begin{array}{l}\text { Active } \\
\text { vitamin D/ } \\
\text { analogues }\end{array}$ & $\begin{array}{l}\text { Calcitriol } \\
\text { Paricalcitol }\end{array}$ & $\forall$ & & & & \\
\hline \multicolumn{2}{|c|}{$\begin{array}{l}\text { The ideal SHPT treatment in } \\
\text { non-dialysis CKD }\end{array}$} & $\widehat{\hat{1}}$ & - & - & & - \\
\hline
\end{tabular}

$C a$ calcium, $C K D$ chronic kidney disease, $F G F-23$ fibroblast growth factor $23, I R$ immediate release, $M B D$ mineral and bone disorder, $P$ phosphate, $P T H$ parathyroid hormone, secondary hyperparathyroidism secondary hyperparathyroidism, $25(\mathrm{OH}) \mathrm{D} 25$-hydroxyvitamin D 
Fig. 1 Effect of bolus i.v. or oral extended-release calcifediol administration on serum levels of calcifediol and 1,25-dihydroxyvitamin $\mathrm{D}$ in patients with stage 3 or 4 CKD, secondary hyperparathyroidism and vitamin D insufficiency. Patients received a single bolus i.v. injection of $448 \mathrm{mg}$ calcifediol (solid circles) or single doses of oral extended-release calcifediol (450 mg-solid triangles; $900 \mathrm{mg}$ — solid squares). Serum samples obtained at the indicated time points were analysed for a calcifediol (25(OH)D3) and $\mathbf{b}$ 1,25-dihydroxyvitamin D. Data are corrected for baseline values. Asterisk denotes significant differences at all time points post-treatment between i.v. and extended-release treatment groups $(\mathrm{p}<0.05)$. MR: modified release formulation providing extended-release (From Petkovich et al. [42])
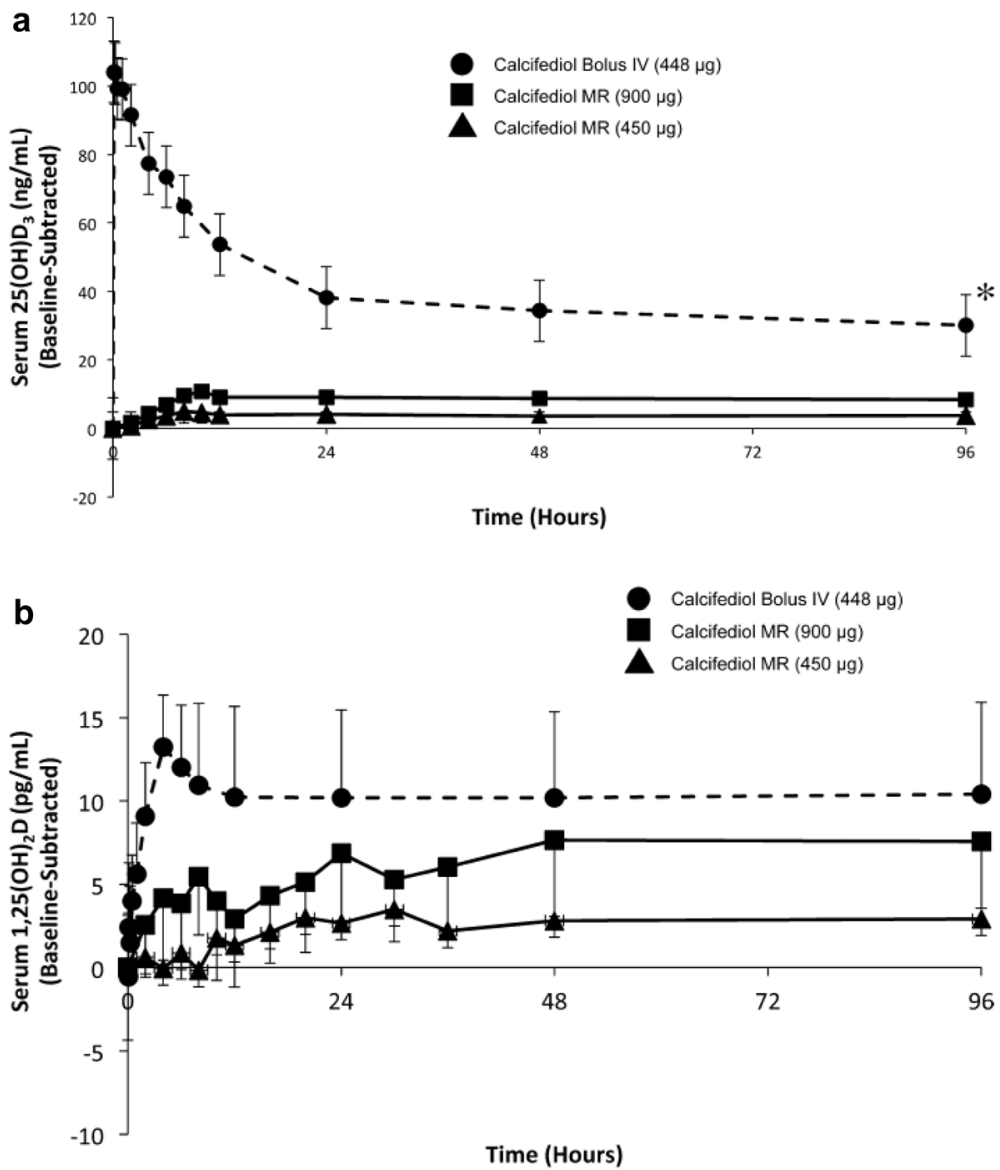

approved in the US, Canada and Europe for treating adults with stage 3-4 CKD and vitamin D insufficiency [21, 22]. Rayaldee ${ }^{\circledR}$ is formulated in capsules containing $30 \mu \mathrm{g}$ of calcifediol monohydrate in a lipophilic excipient mixture (mineral oil, mono- and diglycerides, paraffin, hydroxypropyl methylcellulose, lauroyl polyoxylglycerides, dehydrated alcohol and butylated hydroxytoluene) [21], which provides extended release over a 12-h period [42]. Steady-state levels of $25(\mathrm{OH}) \mathrm{D}$ are achieved after approximately 3 months of treatment [43].

After administration of Rayaldee ${ }^{\circledR}, 25(\mathrm{OH}) \mathrm{D} 3$ is extensively (>98\%) bound to plasma proteins. The mean apparent volume of distribution is $8.8 \mathrm{~L}$ in healthy subjects following a single oral dose of Rayaldee ${ }^{\circledR}$, and $30.1 \mathrm{~L}$ in patients with stage 3 or 4 chronic kidney disease following repeated dosing [21].

\section{Pharmacology}

The extended-release strategy is designed to gradually increase serum total $25(\mathrm{OH}) \mathrm{D}$ concentrations to targeted levels, while avoiding upregulation of FGF23 and vitamin D catabolism through CYP24A1. Moreover, activation of this prohormone is tightly controlled at renal and extra-renal levels by the requirement for CYP27B $11 \alpha$-hydroxylase activation to $1,25(\mathrm{OH}) 2 \mathrm{D}$, thereby reducing the risk of hypercalcaemia and ectopic calcification [42].

In patients with stage $3 / 4 \mathrm{CKD}$, single-dose administration of extended-release calcifediol did not cause a rapid rise in $25(\mathrm{OH}) \mathrm{D}$ or trigger catabolism. In a proof-of-concept study, 29 patients with stage 3/4 CKD, secondary hyperparathyroidism and vitamin $\mathrm{D}$ insufficiency (serum total $25(\mathrm{OH}) \mathrm{D}<30 \mathrm{ng} / \mathrm{mL})$ were randomised to receive either a single bolus i.v. injection of calcifediol (448 $\mu \mathrm{g})$ or a single oral dose of extended-release calcifediol (either $450 \mu \mathrm{g}$ or $900 \mu \mathrm{g}$ ) [42]. The rapid rise in serum 25(OH)D after the i.v. bolus (Fig. 1a) resulted in a rapid rise in activated $1,25(\mathrm{OH}) 2 \mathrm{D}$ that was not observed with either of the oral doses administered (Fig. 1b).

As shown in Fig. 1, only a small fraction of the circulating $25(\mathrm{OH}) \mathrm{D}$ (Panel A) is transformed into activated 1,25(OH) D (Panel B), i.e., less than $0.1 \%$ on average [44]. When steady plasma levels are achieved after $48 \mathrm{~h}$, the estimated conversion rates after the administration of 450 and $900 \mu \mathrm{g}$ of Rayaldee ${ }^{\circledR}$ are 0.075 and $0.094 \%$, respectively, which is approximately 3 -fold higher compared to $0.03 \%$ observed after administration of an i.v. bolus of $448 \mu \mathrm{g}$ of $25(\mathrm{OH}) \mathrm{D}$. 
Table 2 Available treatment options for secondary hyperparathyroidism in patients with chronic kidney disease (Adapted from Cozzolino et al. [29])

\begin{tabular}{|c|c|c|c|}
\hline Drug class & Drugs(s) & Current therapeutic uses & $\begin{array}{l}\text { Mechanism and site(s) of metabolism/ } \\
\text { activation }\end{array}$ \\
\hline Nutritional vitamin D & $\begin{array}{l}\text { Cholecalciferol } \\
\text { Ergocalciferol }\end{array}$ & $\begin{array}{l}\text { Treatment/prevention of vitamin D } \\
\text { deficiency; in combination therapies to } \\
\text { treat bone conditions such as osteopo- } \\
\text { rosis; maintenance of vitamin D levels, } \\
\text { treatment of disease associated with } \\
\text { vitamin D malabsorption }\end{array}$ & $\begin{array}{l}\text { Physiological Activation needed (liver } \\
\text { and kidney) }\end{array}$ \\
\hline \multirow[t]{2}{*}{$\begin{array}{l}\text { Non- } 1 \alpha \text {-hydroxylated vita- } \\
\text { min D prohormones }\end{array}$} & Immediate-release calcifediol & $\begin{array}{l}\text { Prevention of vitamin D deficiency } \\
\text { in renal failure and osteomalacia in } \\
\text { adults, prevention of calcium disor- } \\
\text { ders, treatment of rickets in children }\end{array}$ & $\begin{array}{l}\text { Physiological activation needed } \\
\text { (primarily kidney, some extra-renal } \\
\text { tissues) }\end{array}$ \\
\hline & Extended-release calcifediol & $\begin{array}{l}\text { Treatment of secondary hyperparathy- } \\
\text { roidism in adults with stage } 3 \text { or } 4 \\
\text { CKD and serum total } 25 \text {-hydroxyvita- } \\
\text { min D levels }<30 \mathrm{ng} / \mathrm{mL}\end{array}$ & \\
\hline Active vitamin D hormone & Calcitriol & $\begin{array}{l}\text { Correction of calcium and phosphate } \\
\text { metabolism abnormalities in adults } \\
\text { with osteodystrophy; treatment } \\
\text { of post-menopausal osteoporosis; } \\
\text { treatment/prevention of secondary } \\
\text { hyperparathyroidism }{ }^{\mathrm{a}} \text { in non-dialysis } \\
\text { CKD and dialysis CKD }\end{array}$ & Pharmacological \\
\hline 1- $\alpha$ hydroxylated analogues & $\begin{array}{l}\text { Paricalcitol } \\
\text { Doxercalciferol } \\
\text { Alfacalcidol }\end{array}$ & $\begin{array}{l}\text { Correction of calcium and phosphate } \\
\text { metabolism abnormalities in adults } \\
\text { with osteodystrophy; treatment } \\
\text { of post-menopausal osteoporosis; } \\
\text { treatment/prevention of secondary } \\
\text { hyperparathyroidism }{ }^{\mathrm{a}} \text { in non-dialysis } \\
\text { CKD and dialysis }\end{array}$ & $\begin{array}{l}\text { Hepatic activation needed for doxercal- } \\
\text { ciferol and alfacalcidol }\end{array}$ \\
\hline
\end{tabular}

${ }^{a}$ Not all active vitamin D and analogues are indicated for secondary hyperparathyroidism

$C K D$ chronic kidney disease

Thus, the more gradual increase in plasma $25(\mathrm{OH}) \mathrm{D}$ levels obtained with Rayaldee ${ }^{\circledR}$ translates into an optimal conversion rate, most likely because the subsequent slower increase in activated $1,25(\mathrm{OH}) \mathrm{D}$ reduces its own catabolism by CYP24A1 [42]. Interestingly, the 25(OH)D conversion rate $48 \mathrm{~h}$ after administration of $900 \mu \mathrm{g}$ of Rayaldee ${ }^{\circledR}$ appears to be higher in patients with CKD compared to healthy subjects ( 0.094 vs. $0.053 \%$, respectively) [Unpublished data on file]. However, a relationship between the rate of $25(\mathrm{OH}) \mathrm{D}$ conversion and its clinical efficacy in CKD remains to be established.

Pharmacokinetic data on extended-release calcifediol provide the basis to explore the relationships existing between circulating 25(OH)D levels and biomarkers of CKD. Parathyroid hormone levels decreased significantly with extended-release calcifediol $900 \mathrm{mg}$, compared to the i.v. calcifediol bolus.

In a secondary analysis of pooled data from the 2 most recent RCTs conducted with extended-release calcifediol in patients with stage 3 or 4 CKD [19], the mean plasma concentration of intact parathyroid hormone at the end of treatment was inversely proportional to the mean serum 25(OH)D concentration (Fig. 2). In contrast, mean serum total $1,25(\mathrm{OH})_{2} \mathrm{D}$ concentration was directly proportional to the mean serum 25(OH)D concentration (Fig. 3). These findings support the conclusion that Rayaldee ${ }^{\circledR}$ lowers elevated plasma intact parathyroid hormone by raising serum total $25(\mathrm{OH}) \mathrm{D}$, and that the mechanism for plasma intact parathyroid hormone suppression is elevation of serum total $1,25(\mathrm{OH}) 2 \mathrm{D}$.

\section{Clinical studies}

Sprague et al. conducted a 12-week randomized, doubleblind, placebo-controlled trial that evaluated the efficacy of extended-release calcifediol in 78 patients with CKD, parathyroid hormone $>70 \mathrm{pg} / \mathrm{mL}$ and serum total $25(\mathrm{OH})$ $\mathrm{D}<30 \mathrm{ng} / \mathrm{mL}$ [17]. Patients were randomised to receive daily oral extended-release calcifediol (30, 60 or $90 \mu \mathrm{g}$ ), or placebo. Serum $25(\mathrm{OH}) \mathrm{D}$ levels increased in proportion to dosage (Fig. 4). At end of treatment after 6 weeks, 
serum 25(OH)D levels had normalised ( $\geq 30 \mathrm{ng} / \mathrm{mL})$ in $90 \%$ of patients treated with extended-release calcifediol vs $3 \%$ with placebo $(\mathrm{p}<0.0001)$, and mean serum $25(\mathrm{OH}) \mathrm{D}$ among all extended-release calcifediol-treated patients was $64.4 \pm 24.9 \mathrm{ng} / \mathrm{mL}$ vs $18.5 \pm 5.3$ with placebo $(\mathrm{p}<0.0001)$. extended-release calcifediol was well-tolerated and there were no clinically significant safety concerns.

The percent change from baseline in parathyroid hormone with extended-release calcifediol increased with increasing extended-release calcifediol dosage administered (Fig. 5).

The efficacy and safety of extended-release calcifediol were evaluated further in two identical 26-week randomised, placebo-controlled, double-blind trials in patients with stage 3/4 CKD, secondary hyperparathyroidism, and vitamin D insufficiency (serum total 25(OH)D 10-30 ng/mL) [43]. Patients were randomized $(2: 1)$ to receive extended-release calcifediol once daily ( $30 \mu$ g for 12 weeks, followed by either 30 or $60 \mu \mathrm{g}$ for 14 weeks), or placebo. At week 13, the extended-release calcifediol dose was increased if serum parathyroid hormone was $>70 \mathrm{pg} / \mathrm{mL}$, serum $25(\mathrm{OH}) \mathrm{D}$ was $<65 \mathrm{ng} / \mathrm{mL}$, and serum calcium level remained $<9.8 \mathrm{mg} / \mathrm{dL}$. In a 26-week, open-label extension of these two studies, 298 patients continued receiving their extended-release calcifediol dosing level or crossed over from placebo to extendedrelease calcifediol (Fig. 6).

Extended-release calcifediol normalized serum total $25(\mathrm{OH}) \mathrm{D}$ levels in $>95 \%$ of the per protocol population and was well-tolerated, without clinically relevant effects on serum calcium, phosphorus, or FGF23 levels. The lack of effect on FGF23 suggests that extended-release calcifediol does not activate the vitamin $\mathrm{D}$ catabolic feedback mechanism involving 24-hydroxylase [19].

Oversuppression of parathyroid hormone is a concern in patients with stage 3-4 CKD treated with calcitriol or active analogues because low parathyroid hormone concentration is associated with adynamic bone disease and hypercalcaemia [26, 36]. Randomized controlled trials have shown that extended-release calcifediol gradually but effectively reduces parathyroid hormone levels without causing oversuppression.

Post hoc analysis of this data examined the impact of baseline parathyroid hormone levels on end-of-treatment parathyroid hormone levels [45]. Extended-release calcifediol and placebo had similar, minor effects on mean serum calcium and phosphorous. Extended-release calcifediol increased serum $25(\mathrm{OH}) \mathrm{D}$ and $1,25(\mathrm{OH})_{2} \mathrm{D}$ significantly and to comparable levels regardless of baseline intact parathyroid hormone tertile. However, decreases in mean intact parathyroid hormone with extended-release calcifediol differed between baseline intact parathyroid hormone tertiles and were directly proportional to baseline levels. Oversuppression of intact parathyroid hormone was not observed. The mean absolute intact parathyroid hormone reductions

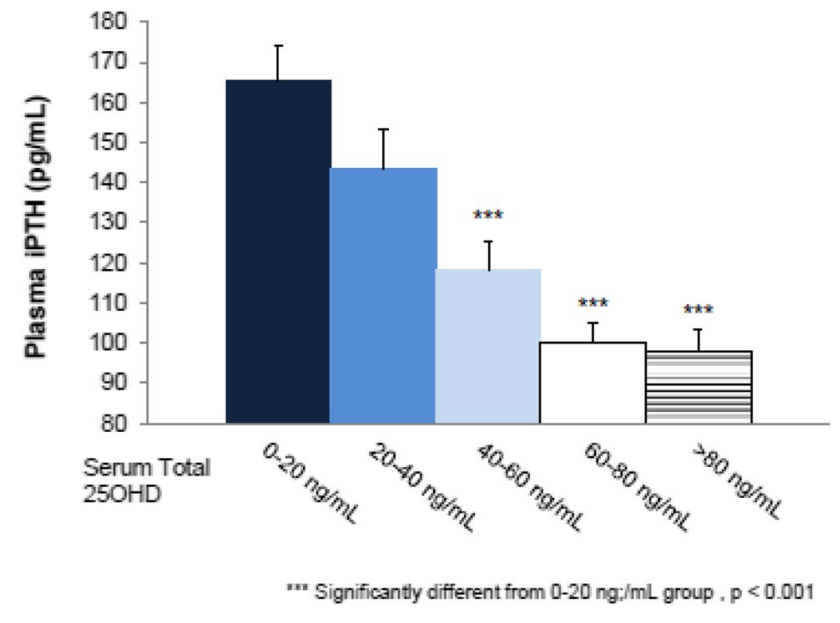

Fig. 2 Mean $( \pm S E)$ plasma intact parathyroid hormone versus mean serum total 25-hydroxyvitamin $\mathrm{D}(\mathrm{ng} / \mathrm{mL})$ during the efficacy assessment period in the per protocol population (Sprague et al. [24])

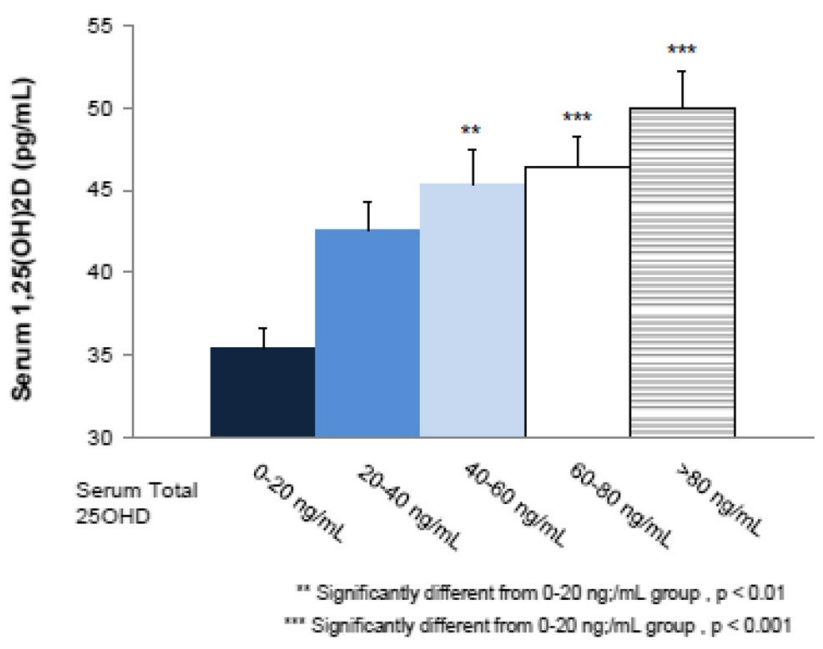

Fig. 3 Mean $( \pm \mathrm{SE})$ serum total 1,25-dihydroxyvitamin $\mathrm{D}(\mathrm{pg} / \mathrm{mL})$ versus serum total 25 -hydroxyvitamin $\mathrm{D}(\mathrm{ng} / \mathrm{mL})$ during the efficacy assessment period in the per protocol population (Sprague et al. [24])

that were proportional to baseline intact parathyroid hormone levels is consistent with a mechanism of action involving physiological regulation of intact parathyroid hormone modulated by secondary hyperparathyroidism severity.

Strugnell et al. [19], conducted a post hoc analysis of aggregated data from two phase 3 studies by Sprague et al. $[17,43]$ to examine possible relationships between posttreatment $25(\mathrm{OH}) \mathrm{D}$ quintile and associated changes in factors relevant to CKD-mineral and bone disorder, including plasma intact parathyroid hormone, serum bone turnover markers, calcium, phosphorus, intact FGF23 and vitamin D metabolites, estimated glomerular filtration rate, and urine calcium/creatinine ratio. 
Progressive increases in serum 1,25-dihydroxyvitamin D and reductions in plasma intact parathyroid hormone and serum bone turnover markers were observed as mean posttreatment serum 25(OH)D rose from $13.9 \mathrm{ng} / \mathrm{mL}$ (in Quintile 1) to $92.5 \mathrm{ng} / \mathrm{mL}$ (in Quintile 5), regardless of CKD stage. Mean serum calcium, phosphorus and FGF23 levels, estimated glomerular filtration rate and urine calcium/creatinine ratio (collectively "safety parameters") did not change significantly from Quintile 1. Suppression of intact parathyroid hormone and bone turnover markers was not observed until serum $25(\mathrm{OH}) \mathrm{D}$ rose to at least $50.8 \mathrm{ng} / \mathrm{mL}$ (Quintile 3) (Fig. 7). This has been interpreted as an indication that current targets for vitamin D repletion therapy in CKD may be too low [19], because the mean serum 25(OH)D of $92.5 \mathrm{ng} /$ $\mathrm{mL}$ in the $5^{\text {th }}$ quintile was not associated with undesirable changes in safety parameters, but did result in a progressive increase in the percentage of patients with parathyroid hormone reductions $\geq 30 \%$.

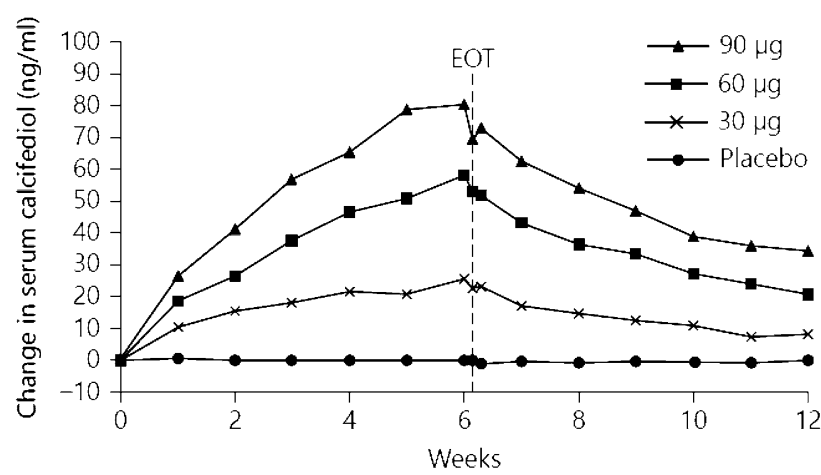

Fig. 4 Changes from baseline in serum 25(OH)D concentrations during the 6-week treatment period according to the extended-release calcifediol dose administered $(30,60$ or $90 \mu \mathrm{g} /$ day). EOT, end of treatment (From Sprague et al. [17])

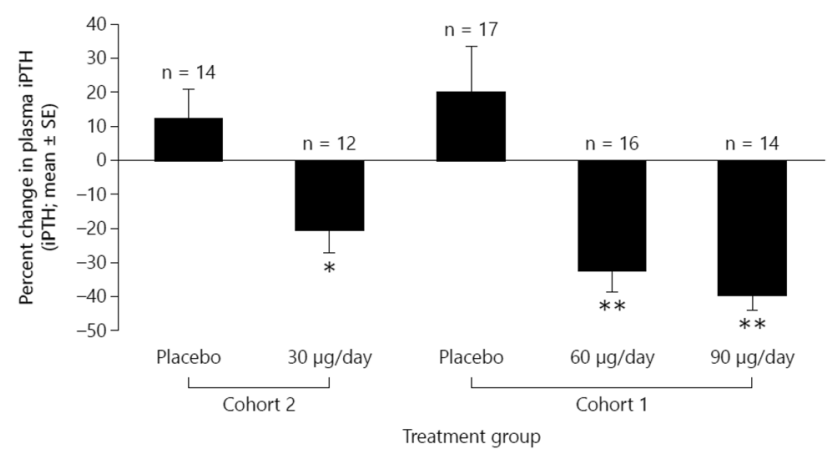

Fig. 5 Percent changes from baseline in plasma intact parathyroid hormone at the end of the 6-week treatment period according to the administered extended-release calcifediol dose (30, 60 or $90 \mu \mathrm{g} /$ day). *Significantly different from placebo, $\mathrm{p}<0.05$; **Significantly different from placebo, $\mathrm{p}<0.001$ (From Sprague et al. [17])
Thus, meaningful reductions in parathyroid hormone require serum $25(\mathrm{OH}) \mathrm{D}$ levels above the guideline-recommended targets [20]. The results also suggest that higher serum $25(\mathrm{OH}) \mathrm{D}$ levels can be achieved in patients with stage 3/4 CKD without sacrificing safety. These findings are consistent with the results of a large cross-sectional analysis of 14,289 unselected patients with CKD stage 1-5 that revealed a progressive lowering of parathyroid hormone up to $25(\mathrm{OH}) \mathrm{D}$ levels of $42-48 \mathrm{ng} / \mathrm{mL}$, with a somewhat decreasing response above that level [18]. Also in that study, there was no association between higher $25(\mathrm{OH}) \mathrm{D}$ levels and hyperphosphataemia or hypercalcaemia.

A recent real-world study conducted on clinical records from 18 Nephrology clinics in the US compared the effects of nutritional vitamin $\mathrm{D}(\mathrm{n}=147)$, extended-release calcifediol $(n=174)$, and active vitamin $D$ agents $(n=55)$ on levels of $25(\mathrm{OH}) \mathrm{D}$, parathyroid hormone, calcium, and phosphorus levels after $\geq 20$ weeks of follow-up in adults with stage 3 or 4 CKD. The clinical effectiveness and safety of extendedrelease calcifediol in the real-world setting was consistent with what has been reported in randomised clinical trials. Only extended-release calcifediol was associated with a statistically significant decrease in parathyroid hormone ( $-34 \mathrm{ng} / \mathrm{mL} ; \mathrm{p}<0.001)$. Extended-release calcifediol did not have a statistically significant effect on serum calcium or phosphate levels [46].

\section{Position of extended-release calcifediol in current therapy for secondary hyperparathyroidism}

Treatment of secondary hyperparathyroidism in patients with CKD stages 3 or 4 and vitamin D deficiency should aim to control parathyroid hormone levels early in the disease course, while parathyroid cells are still responsive to physiological 1,25(OH)2D signalling. Although there is no consensus on the optimal serum 25(OH)D concentration or parathyroid hormone targets in patients with secondary hyperparathyroidism, recent evidence suggests that $25(\mathrm{OH})$ D levels $>50 \mathrm{ng} / \mathrm{mL}$ are required to effectively reduce parathyroid hormone levels [18].

Guidelines recommend nutritional vitamin D supplements for treating secondary hyperparathyroidism in patients with non-dialysis $\mathrm{CKD}$, and suggest that active vitamin $\mathrm{D}$ (calcitriol) and analogues should be reserved for patients with advanced CKD, uncontrolled parathyroid hormone levels that are rising quickly, and for patients on dialysis [20]. However, nutritional forms of vitamin D and immediate release formulations of calcifediol have only modest effects on parathyroid hormone levels and are associated with increased risk for hypercalcaemia, especially when 


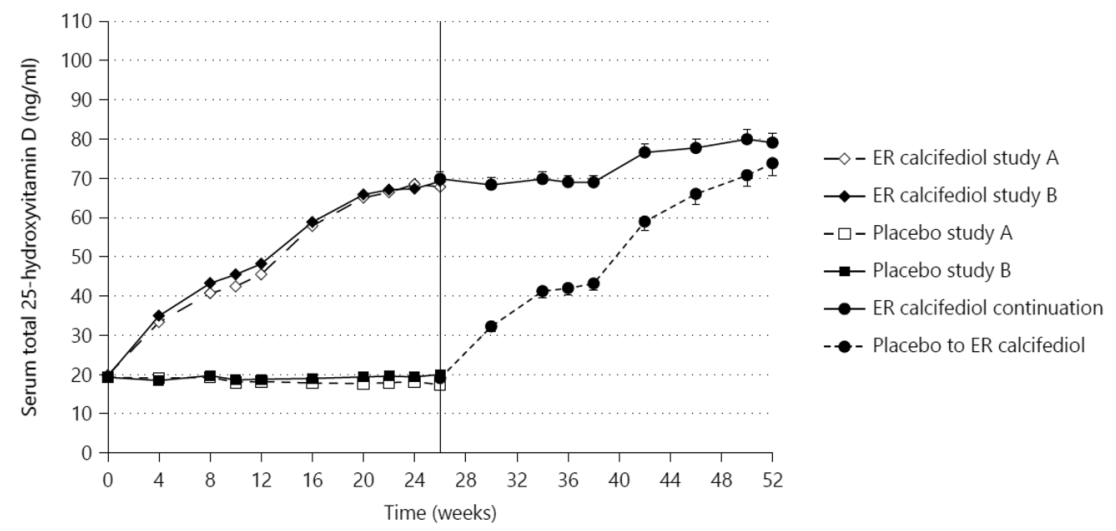

Fig. 6 Mean (SE) change over time in serum total 25(OH)D in the combined per protocol population. Data points from 0 to 26 weeks represent mean values for individual time points from placebocontrolled studies A and B. Error bars in this portion of the figure

administered at high doses; moreover, these agents appear to trigger catabolism of vitamin D sterols.

Calcitriol and active vitamin D analogues are effective for lowering parathyroid hormone levels but are associated with even higher risks of hypercalcaemia. At the same time, they must be administered with a nutritional vitamin D agent (dual therapy) because they do not replenish 24(OH)D substrate to support pleiotropic (autocrine/paracrine) functions.

Several characteristics of extended-release calcifediol support its use in the intermediate stages of CKD in patients with secondary hyperparathyroidism and vitamin D insufficiency. Extended-release calcifediol reduced parathyroid hormone levels to an extent comparable to what can be achieved with the combination of active vitamin $\mathrm{D}$ analogues combined with natural vitamin D agents. In clinical trials, monotherapy with extended-release calcifediol in patients with stage 3 or 4 CKD achieves dose-dependent increases of $25(\mathrm{OH}) \mathrm{D}$ and physiological increases in $1,25(\mathrm{OH}) 2 \mathrm{D}$, accompanied by sustained reduction of parathyroid hormone and little or no impact on mineral balance or FGF23 levels. Meanwhile, emerging data from real-world clinical experience with extended-release calcifediol for patients with stage 3 or 4 CKD suggest that it is comparable to active vitamin $\mathrm{D}$ analogues for controlling parathyroid hormone levels, but has the added benefit of replenishing 25(OH)D [46].

In Fig. 8, we propose a flowchart for treating secondary hyperparathyroidism in patients with CKD stage 3-4. In patients with serum $25(\mathrm{OH}) \mathrm{D}$ levels $>=30 \mathrm{ng} / \mathrm{mL}$ and serum $\mathrm{Ca}, \mathrm{P}$, and parathyroid hormone in the normal range, there is no need to start therapy for secondary hyperparathyroidism. In patients with $25(\mathrm{OH}) \mathrm{D}<30 \mathrm{ng} / \mathrm{mL}$ and serum $\mathrm{Ca}$, $\mathrm{P}$, and parathyroid hormone in the normal range, we suggest using nutritional vitamin $\mathrm{D}$, such as cholecalciferol. In patients with $25(\mathrm{OH}) \mathrm{D}$ $<30 \mathrm{ng} / \mathrm{mL}$ and parathyroid hormone levels in the upper normal are omitted for clarity. Data points from 26 to 52 weeks represent mean $\pm \mathrm{SE}$ values for data from the open-label extension study. SE values for 0-26 weeks were of similar magnitude to those in the open-label extension (From Sprague et al. [44])

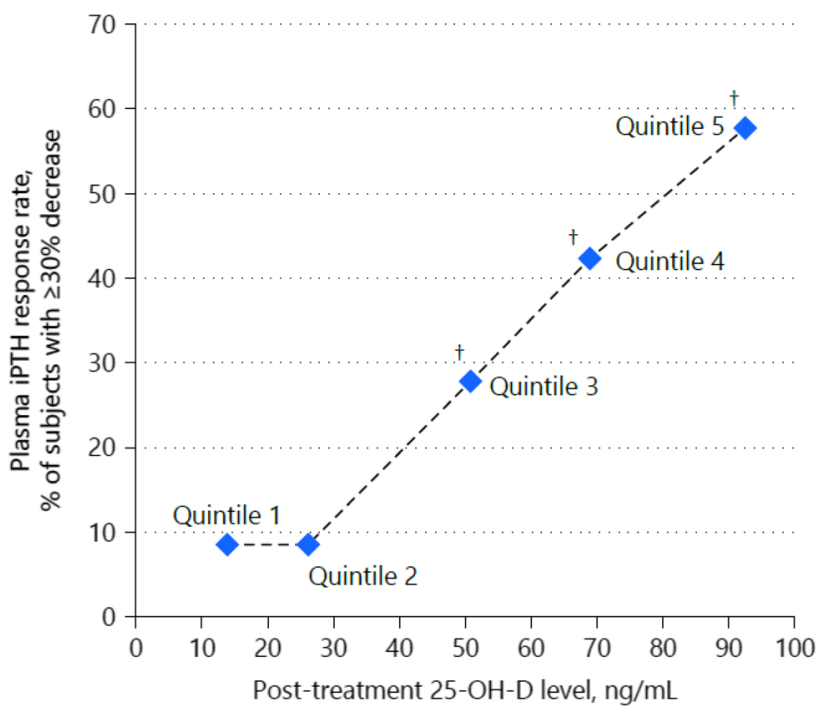

Fig. 7 Analysis of plasma intact parathyroid hormone response rates by posttreatment $25(\mathrm{OH}) \mathrm{D}$ Quintile. The proportion of per protocol subjects achieving an intact parathyroid hormone response, defined as a mean decrease of $\geq 30 \%$ in plasma intact parathyroid hormone from pre-treatment baseline, was analysed as a function of mean posttreatment serum total 25(OH)D quintile (from Strugnell et al. [19]). ${ }^{\dagger} \mathrm{Sig}$ nificantly different from Quintile $1, \mathrm{p}<0.05 ; i P T H$ intact parathyroid hormone

range or higher, we suggest administering ERC, which should be continued if secondary hyperparathyroidism is controlled; if serum parathyroid hormone levels remain persistently elevated, we suggest continuing extended-release calcifediol therapy or replacing it with a nutritional vitamin $\mathrm{D}$ and combining this with an active vitamin D or vitamin D analogue (Fig. 9). 


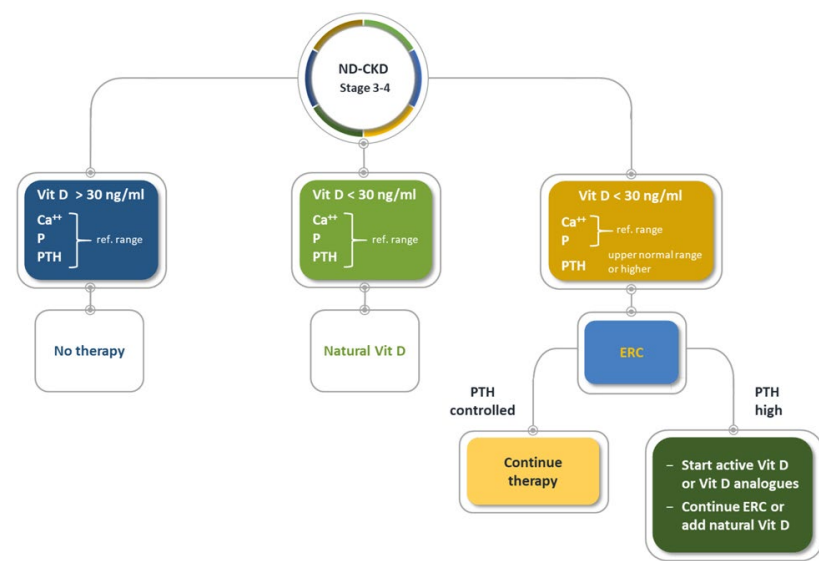

Fig. 8 Flowchart for managing patients with nondialysis-CKD stage 3-4. ERC extended-release calcifediol, parathyroid hormone parathyroid hormone, Vit $D$ vitamin D

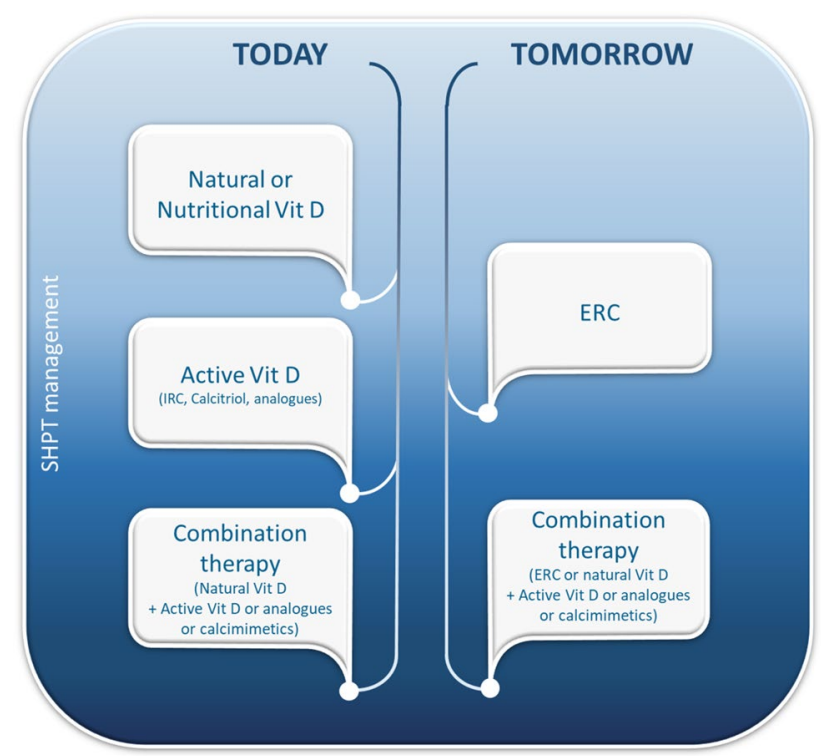

Fig. 9 Current and future management of secondary hyperparathyroidism in patients with CKD and hypovitaminosis $\mathrm{D}$. Vit $D$ vitamin D IRC immediate-release calciferol, $E R C$ extended-release calciferol, secondary hyperparathyroidism secondary hyperparathyroidism

\section{Conclusion}

Treatment for patients with intermediate-stage non-dialysis CKD and vitamin D deficiency should aim to replenish $25(\mathrm{OH}) \mathrm{D}$ levels with a nutritional form of vitamin $\mathrm{D}$. If secondary hyperparathyroidism is present, treatment should aim to control parathyroid hormone levels early in the disease course. This may require targeting serum $25(\mathrm{OH}) \mathrm{D}$ levels $>50 \mathrm{ng} / \mathrm{mL}$. Nutritional forms of vitamin $\mathrm{D}$ and immediate release formulations of calcifediol have only modest effects on parathyroid hormone levels. In this setting, monotherapy with extended-release calcifediol achieves dose-dependent increases of 25(OH)D and physiological increases in $1,25(\mathrm{OH}) 2 \mathrm{D}$, with sustained reduction of parathyroid hormone levels, comparable to what can be achieved with active vitamin D analogues; however, extended-release calcifediol does so with less risk of hypercalcaemia and has the added benefit of also replenishing 25(OH)D.

Author contributions All authors contributed to the design and implementation of the research, to the analysis of the results and to the writing of the manuscript.

Funding Open access funding provided by Università degli Studi di Milano within the CRUI-CARE Agreement. The work was supported by Ethos srl.

Availability of data and material Not applicable.

Code availability Not applicable.

\section{Compliance with ethical standards}

Conflict of interest MC declares advisory/lecture fees from Amgen, Abbvie, Shire, Vifor-Pharma, and Baxter. PM declares no competing interest. PN has attended a board meeting supported by Vifor Pharma.

Ethical approval This article does not contain any studies with human participants performed by any of the authors

Open Access This article is licensed under a Creative Commons Attribution 4.0 International License, which permits use, sharing, adaptation, distribution and reproduction in any medium or format, as long as you give appropriate credit to the original author(s) and the source, provide a link to the Creative Commons licence, and indicate if changes were made. The images or other third party material in this article are included in the article's Creative Commons licence, unless indicated otherwise in a credit line to the material. If material is not included in the article's Creative Commons licence and your intended use is not permitted by statutory regulation or exceeds the permitted use, you will need to obtain permission directly from the copyright holder. To view a copy of this licence, visit http://creativecommons.org/licenses/by/4.0/.

\section{References}

1. Hill NR, Fatoba ST, Oke JL et al (2016) Global prevalence of chronic kidney disease - a systematic review and meta-analysis. PLoS ONE 11:e0158765. https://doi.org/10.1371/journal.pone. 0158765

2. Ketteler M, Block GA, Evenepoel P et al (2018) Diagnosis, evaluation, prevention, and treatment of chronic kidney disease-mineral and bone disorder: synopsis of the kidney disease: improving global outcomes 2017 clinical practice guideline update. Ann Intern Med 168:422-430. https://doi.org/10.7326/M17-2640

3. Darlington O, Dickerson C, Evans M et al (2021) Costs and healthcare resource use associated with risk of cardiovascular morbidity in patients with chronic kidney disease: evidence from 
a systematic literature review. Adv Ther 38:994-1010. https://doi. org/10.1007/s12325-020-01607-4

4. Legrand K, Speyer E, Stengel B et al (2020) Perceived health and quality of life in patients with CKD, including those with kidney failure: findings from national surveys in France. Am J Kidney Dis 75:868-878. https://doi.org/10.1053/j.ajkd.2019.08.026

5. Cunningham J, Locatelli F, Rodriguez M (2011) Secondary hyperparathyroidism: pathogenesis, disease progression, and therapeutic options. Clin J Am Soc Nephrol 6:913-921. https://doi.org/10. 2215/CJN.06040710

6. Levin A, Bakris GL, Molitch M et al (2007) Prevalence of abnormal serum vitamin $\mathrm{D}, \mathrm{PTH}$, calcium, and phosphorus in patients with chronic kidney disease: results of the study to evaluate early kidney disease. Kidney Int 71:31-38. https://doi.org/10.1038/sj. ki.5002009

7. Geng S, Kuang Z, Peissig PL et al (2019) Parathyroid hormone independently predicts fracture, vascular events, and death in patients with stage 3 and 4 chronic kidney disease. Osteoporos Int 30:2019-2025. https://doi.org/10.1007/s00198-019-05033-3

8. Shimada T, Hasegawa H, Yamazaki Y et al (2004) FGF-23 is a potent regulator of vitamin D metabolism and phosphate homeostasis. J Bone Miner Res 19:429-435. https://doi.org/10.1359/ JBMR.0301264

9. Messa P, Alfieri CM (2019) Secondary and tertiary hyperparathyroidism. Front Horm Res 51:91-108. https://doi.org/10.1159/ 000491041

10. Mehrotra R, Kermah D, Budoff M et al (2008) Hypovitaminosis D in chronic kidney disease. Clin J Am Soc Nephrol 3:1144-1151. https://doi.org/10.2215/CJN.05781207

11. Jean G, Souberbielle JC, Chazot C (2017) Vitamin D in chronic kidney disease and dialysis patients. Nutrients 9:328. https://doi. org/10.3390/nu9040328

12. Michaud J, Naud J, Ouimet D et al (2010) Reduced hepatic synthesis of calcidiol in uremia. J Am Soc Nephrol 21:1488-1497. https://doi.org/10.1681/ASN.2009080815

13. Petkovich M, Jones G (2011) CYP24A1 and kidney disease. Curr Opin Nephrol Hypertens 20:337-344. https://doi.org/10.1097/ MNH.0b013e3283477a7b

14. Melamed ML, Chonchol M, Gutiérrez OM et al (2018) The role of vitamin D in CKD stages 3 to 4: report of a scientific workshop sponsored by the National Kidney Foundation. Am J Kidney Dis 72:834-845. https://doi.org/10.1053/j.ajkd.2018.06.031

15. National Kidney Foundation (2003) K/DOQI clinical practice guidelines for bone metabolism and disease in chronic kidney disease. Am J Kidney Dis 42:S1-201

16. Holick MF, Binkley NC, Bischoff-Ferrari HA et al (2011) Evaluation, treatment, and prevention of vitamin D deficiency: an Endocrine Society clinical practice guideline. J Clin Endocrinol Metab 96:1911-1930. https://doi.org/10.1210/jc.2011-0385

17. Sprague SM, Silva AL, Al-Saghir F et al (2014) Modified-release calcifediol effectively controls secondary hyperparathyroidism associated with vitamin D insufficiency in chronic kidney disease. Am J Nephrol 40:535-545. https://doi.org/10.1159/000369939

18. Ennis JL, Worcester EM, Coe FL, Sprague SM (2016) Current recommended 25-hydroxyvitamin D targets for chronic kidney disease management may be too low. J Nephrol 29:63-70. https:// doi.org/10.1007/s40620-015-0186-0

19. Strugnell SA, Sprague SM, Ashfaq A et al (2019) Rationale for raising current clinical practice guideline target for serum 25-hydroxyvitamin D in chronic kidney disease. Am J Nephrol 49:284-293. https://doi.org/10.1159/000499187

20. Kidney Disease: Improving Global Outcomes (KDIGO) CKDMBD Work Group (2009) KDIGO clinical practice guideline for the diagnosis, evaluation, prevention, and treatment of Chronic Kidney Disease-Mineral and Bone Disorder (CKD-MBD). Kidney Int Suppl. https://doi.org/10.1038/ki.2009.188
21. US Food and Drug Administration (2019) Rayaldee prescribing information. https://www.accessdata.fda.gov/drugsatfda_docs/ label/2019/208010s005lbl.pdf. Accessed 4 Mar 2021

22. Health Canada (2018) Rayaldee product monograph including patient medication information. https://pdf.hres.ca/dpd_pm/00046 289.PDF. Accessed 4 Mar 2021

23. Kramer H, Berns JS, Choi MJ et al (2014) 25-Hydroxyvitamin D testing and supplementation in CKD: an NKF-KDOQI controversies report. Am J Kidney Dis 64:499-509. https://doi.org/10. 1053/j.ajkd.2014.05.018

24. Sprague SM, Strugnell SA, Bishop CW (2017) Extended-release calcifediol for secondary hyperparathyroidism in stage 3-4 chronic kidney disease. Expert Rev Endocrinol Metab 12:289301. https://doi.org/10.1080/17446651.2017.1347501

25. Gallieni M, De Luca N, Santoro D et al (2016) Management of CKD-MBD in non-dialysis patients under regular nephrology care: a prospective multicenter study. J Nephrol 29:71-78. https:// doi.org/10.1007/s40620-015-0202-4

26. Kidney Disease: Improving Global Outcomes (KDIGO) CKDMBD Update Work, (2017) KDIGO 2017 Clinical practice guideline update for the diagnosis, evaluation, prevention, and treatment of chronic kidney disease-mineral and bone disorder (CKD-MBD). Kidney Int Suppl 7:1-59. https://doi.org/10.1016/j. kisu.2017.04.001

27. Paloian NJ, Giachelli CM (2014) A current understanding of vascular calcification in CKD. Am J Physiol Ren Physiol 307:F891900. https://doi.org/10.1152/ajprenal.00163.2014

28. Dusilová-Sulková S, Šafránek R, Vávrová J et al (2015) Low-dose cholecalciferol supplementation and dual vitamin D therapy in haemodialysis patients. Int Urol Nephrol 47:169-176. https://doi. org/10.1007/s11255-014-0842-7

29. Cozzolino M, Ketteler M (2019) Evaluating extended-release calcifediol as a treatment option for chronic kidney disease-mineral and bone disorder (CKD-MBD). Expert Opin Pharmacother 20:2081-2093. https://doi.org/10.1080/14656566.2019.1663826

30. Agarwal R, Georgianos PI (2016) Con: nutritional vitamin D replacement in chronic kidney disease and end-stage renal disease. Nephrol Dial Transplant 31:706-713. https://doi.org/10.1093/ndt/ gfw080

31. Alvarez JA, Law J, Coakley KE et al (2012) High-dose cholecalciferol reduces parathyroid hormone in patients with early chronic kidney disease: a pilot, randomized, double-blind, placebo-controlled trial. Am J Clin Nutr 96:672-679. https://doi.org/10.3945/ ajen.112.040642

32. Dusso A, González EA, Martin KJ (2011) Vitamin D in chronic kidney disease. Best Pract Res Clin Endocrinol Metab 25:647655. https://doi.org/10.1016/j.beem.2011.05.005

33. Galassi A, Bellasi A, Ciceri P et al (2017) Calcifediol to treat secondary hyperparathyroidism in patients with chronic kidney disease. Expert Rev Clin Pharmacol 10:1073-1084. https://doi. org/10.1080/17512433.2017.1371011

34. Mazur AT, Norman ME (1984) Effects of 25-OHD3 on renal function in pediatric patients with chronic renal failure. Miner Electrolyte Metab 10:351-358

35. Langman CB, Mazur AT, Baron R, Norman ME (1982) 25-hydroxyvitamin D3 (calcifediol) therapy of juvenile renal osteodystrophy: beneficial effect on linear growth velocity. J Pediatr 100:815-820. https://doi.org/10.1016/s0022-3476(82)80602-1

36. Toussaint ND, Damasiewicz MJ (2017) Do the benefits of using calcitriol and other vitamin $D$ receptor activators in patients with chronic kidney disease outweigh the harms? Nephrology (Carlton) 22(Suppl 2):51-56. https://doi.org/10.1111/nep.13026

37. Cozzolino M, Brancaccio D (2008) Emerging role for the vitamin D receptor activator (VDRA), paricalcitol, in the treatment of secondary hyperparathyroidism. Expert Opin Pharmacother 9:947-954. https://doi.org/10.1517/14656566.9.6.947 
38. Li X-H, Feng L, Yang Z-H, Liao Y-H (2015) Effect of active vitamin $\mathrm{D}$ on cardiovascular outcomes in predialysis chronic kidney diseases: a systematic review and meta-analysis. Nephrology (Carlton) 20:706-714. https://doi.org/10.1111/nep.12505

39. Brancaccio D, Bommer J, Coyne D (2007) Vitamin D receptor activator selectivity in the treatment of secondary hyperparathyroidism: understanding the differences among therapies. Drugs 67:1981-1998. https://doi.org/10.2165/00003495-20076 7140-00002

40. Bouillon R, Marcocci C, Carmeliet G et al (2019) Skeletal and extraskeletal actions of vitamin D: current evidence and outstanding questions. Endocr Rev 40:1109-1151. https://doi.org/10.1210/ er.2018-00126

41. Zehnder D, Bland R, Williams MC et al (2001) Extrarenal expression of 25-hydroxyvitamin d(3)-1 alpha-hydroxylase. J Clin Endocrinol Metab 86:888-894. https://doi.org/10.1210/jcem.86.2.7220

42. Petkovich M, Melnick J, White J et al (2015) Modified-release oral calcifediol corrects vitamin D insufficiency with minimal CYP24A1 upregulation. J Steroid Biochem Mol Biol 148:283289. https://doi.org/10.1016/j.jsbmb.2014.11.022

43. Sprague SM, Crawford PW, Melnick JZ et al (2016) Use of extended-release calcifediol to treat secondary hyperparathyroidism in stages 3 and 4 chronic kidney disease. Am J Nephrol 44:316-325. https://doi.org/10.1159/000450766

44. Gibson CC, Davis CT, Zhu W et al (2015) Dietary vitamin D and its metabolites non-genomically stabilize the endothelium. PLoS One 10:e140370. https://doi.org/10.1371/journal.pone. 0140370

45. Sprague SM, Strugnell SA, Ashfaq A et al (2017) American Society of NephrologylKidney Week-Abstract TH-PO515. https:// www.asn-online.org/education/kidneyweek/2017/program-abstr act.aspx? controlId=2787782. Accessed 14 May 2021

46. Germain MJ, Paul KS, Fadda G et al (2020) Real-world assessment: clinical effectiveness and safety of vitamin D therapies in ND-CKD patients. In: European renal association-european dialysis and transplant association virtual meeting. Poster P0901. https://www.era-online.org/en/virtual-meeting/\#!resources/realworld-assessment-clinical-effectiveness-and-safety-of-vitamin-dtherapies-in-nd-ckd-patients. Accessed 4 Mar 2021

Publisher's Note Springer Nature remains neutral with regard to jurisdictional claims in published maps and institutional affiliations. 